\title{
The concept of "home" in relation to a professional"s office, according to the jurisprudence of the European Court of Human Rights
}

\author{
Assistant Professor, PhD Andreea SEUCAN \\ Bucharest University of Economic Studies- Department of Law \\ Email: andreea.seucan@cig.ase.ro
}

\begin{abstract}
The scientific paper covers specific aspects of the concept of home in connection to a professional's office, according to the jurisprudence of the European Court of Human Rights. It focuses on two specific cases (Niemietz v. Germany and Societe Colas Est and Others v. France). The concept of home is usually related to individuals/natural persons and their private issues. What happens if there is no clear separation between business and private life?Can legal persons claim the same protection as individuals, according to the provisions of the Convention for the Protection of Human Rights and Fundamental Freedoms?
\end{abstract}

Key words: home, professionals, European Court of Human Rights

JEL Classification: $K 22$

\section{Introduction}

According to the provisions of Article 8 of the Convention for the Protection of Human Rights and Fundamental Freedoms (Rome, 4.XI.1950- the Convention), called "Right to respect for private and family life":

1. Everyone has the right to respect for his private and family life, his home and his correspondence.

2. There shall be no interference by a public authority with the exercise of this right, except such as is in accordance with the law and is necessary in a democratic society in the interests of national security, public safety or the economic wellbeing of the country, for the prevention of disorder or crime, for the protection of health or morals, or for the protection of the rights and freedoms of others.

The text from Article 8 has been inspired by the provisions of Article 12 of The Universal Declaration of Human Rights: "No one shall be subjected to arbitrary interference with his privacy, family, home or correspondence, or to attacks upon his honor and reputation. Everyone has the right to the protection of the law against such interference or attacks". 
Even though Article 8 is meant to protect four fields of autonomy for a person - the private life, the family life, home and correspondence- these fields do not exclude each other and one measure can represent an interference with private life, as well as with family life ${ }^{1}$.

In its jurisprudence, the Court has explained that the right to a home is related to the safety and wellbeing of a person ${ }^{2}$.

In its classical sense, a home is the place where a person lives permanently. The concept of home, according to the provisions of the Convention, does not overlap with its definitions from the internal legislation of the member states (Bârsan, 2010). The concept of home is an autonomous concept, even though the answer to the question if a certain place is home, according to the provisions of Article 8-1, depends on the circumstances of facts, especially on the existence of sufficient and continuous ties to a specific place.

The extensive interpretation of the concept of home has determined the judges to extend the protection of Article 8 to a professional's office.

In Niemietz versus Germany (1992) ${ }^{3}$, the plaintiff, a lawyer, had complained that the search made to his office was a breach of Article 8 of the Convention. It represented an unjustified interference in the exercise of the right to private life and home.

The case occurred as follows: a letter had been sent to a German judge (Judge Miosga), that related to criminal procedeeings for insulting behaviour, pending before the court against an employer who refused to deduct from his employees salaries and pay over to the tax office the Church tax to which they were liable. The signature on the letter was of a person called Klaus Wegner (a fictitious person), followed by the words „on behalf of the Anti-clerical Working Group of the Freiburg Bunte Liste" and a post-office box number. Mr. Niemetz was connected to the Freiburg Bunte Liste and the Anti-clerical Working Group and a part of the mail for the Bunte Liste had been delivered to his office.

The Munich Public Prosecutor`s Office initiated criminal procedeeings against Klaus Wegner for the offence of insulting behaviour. The impossibility to identify Klaus Wegner led, among other measures, to the issuance of a warrant for the search of the law office of Mr. Niemietz and his colleague.

The German Government challenged the claim of Mr. Niemietz by asserting that Article 8 made a clear distinction between private life and home, on one hand, and professional and business life and premises, on the other hand.

The Court explained that a person (especially a person exercising a liberal profession) may carry on at home work-related activities and personal activities at its office/headquarters. Related to the word "home", the French version of the Convention uses the concept of "domicile", that has a larger meaning than home, allowing

\footnotetext{
${ }^{1}$ www.echr.coe.int - Practical guide on admissibility criteria

2 ECHR, 24 November 1986, Gillow v. The United Kingdom

${ }^{3}$ http://hudoc.echr.coe.int/sites/eng/pages/search.aspx?i=001-57887
} 
for the possibility to include, for instance, the office of a person who performs a liberal activity. The same reasoning could be also applied to the concept of private/business life. By refusing to recognize the protection of Article 8 to professional activities, inequality of treatment could be created ${ }^{4}$.

The Court also decided that, even though the offence in connection with which the search was made (insult/attempt to exercise pressure on a judge) was a serious one, the fact that the warrant had general character and allowed the search and seizure of documents without any limitation was not proportionate to the aim. Furthermore, considering the materials inspected, the search interfered with professional secrecy more than it had been necessary.

As such, the Court allowed protection, according to Article 8 of the Convention, for the business premises of a professional/natural person, for those situations in which there is no clear separation between professional and private premises or between private and professional activities.

In the case Societe Colas Est and Others v. France (2002) ${ }^{5}$, the Court decided that the concept of home could be also applied to all professional and business premises of a company.

In this case, France`s central government authorities instructed the National Investigations Office to carry-out a large scale administrative investigation into the conduct of public-works contractors. Raids were carried out on 19 November 1985 and 15 October 1986. On each occasion the inspectors entered the premises of the companies having as legal ground the provisions of a national Ordinance, adopted in 1945, which did not require any prior judicial authorization. The documents seized led to the application of a fine by the Competition Council in the year 1989.

The companies stated that the raids carried out, without any supervision or restrictions, infringed the right to respect of their home.

The French Government underlined the fact that, although the investigations were made under the 1945 Ordinance, new legal procedural arrangements were created by a new ordinance of 1 December 1986 and the companies had the possibility to use the judicial remedies to challenge the way the inspections had been led. Another important point made was the one that legal persons could not claim a right to the protection of their professional or business premises with as much force as an individual could in relation to his professional or business address. The investigations could not be considered as searches, according to the provisions of the Code of Criminal Procedure, due to the fact that they had not been carried out by senior police officers searching for evidence for criminal offences. The aim was to inspect and obtain documents in the context of an administrative investigation and the decision to impose fines had been taken by an independent authority, the Competition Council.

The main point made by the applicant companies was that there had been no balance between the aims pursued and the measures used. Interference could not be regarded as lawful without supervision or any

\footnotetext{
${ }^{4}$ In Huvig v. France (1990), the Court decided that there had been an interference with private life when telephone tapping covered both business and private calls.

${ }^{5}$ http://hudoc.echr.coe.int/sites/eng/pages/search.aspx?i=001-60431 
constraints on investigative powers. Moreover, the investigators had seized business and personal papers of the employees, without writing an inventory.

The Court decided that, in matters related to the applicability of the concept of home to legal persons, the Convention is to be seen as a "living instrument"6. As such, "building on its dynamic interpretation", it considered that, in certain circumstances, a company`s registered office, branches or other business premises can benefit from the rights guaranteed by Article 8 of the Convention.

Even though the scale of the operations had a justification in the field of preventing anti-competitive practices, the legislation in place should have afforded adequate and effective safeguards against abuse, which had not happened in the case. At the time of the investigations, the inspectors had wide powers and, as such, the exclusive competence to determine the expediency, number, length and scale of inspections. The change of legislation, in the sense of prior authorization by a judge, occurred after the inspections had been carried out.

\section{Conclusion}

The interpretation of the Convention given by the Court points out that the right to the respect of a home is no longer an attribute of a natural person, but also of a legal person. The protection of the Convention can also include a professional's office, the applicability being determined by the specifics of each case.

It is interesting to notice the difference in meaning between the English and the French version of the Convention when it comes to the concept of "home" and "domicile". Our suggestion is to consider the concept which is broader in sense, due to the fact that, as the Court stated, the Convention is a "living instrument" and it must have a "dynamic" interpretation.

\section{References}

Radu Chiriţă, Curtea Europeană a Drepturilor Omului, Culegere de hotărâri 2003, C.H. Beck Publishing House, Bucharest 2007;

Corneliu Bârsan, Convenţia europeană a drepturilor omului. Comentariu pe articole. 2 Publishing House, Bucharest, 2010;

www.echr.coe.int - Practical guide on admissibility criteria

European Court of Human Rights, 24 November 1986, Gillow v.The United Kingdom http://hudoc.echr.coe.int/sites/eng/pages/search.aspx?i=001-57887

http://hudoc.echr.coe.int/sites/eng/pages/search.aspx?i=001-60431

\footnotetext{
${ }^{6}$ In Chappell v. the United Kingdom (1989), the Court decided that a search conducted at the place of a natural person which was, at the same time, private home and registered office of a company run by him, represented an interference related to his home, according to the provisions of Article 8. In Comingersoll v. Portugal (2000) the Court admitted a company`s right (Article 41) to compensation for non-pecuniary damage for breach of the provisions of Article 6-1 ("In the determination of his civil rights and obligations ..., everyone is entitled to a ... hearing within a reasonable time by [a] ... tribunal ..."). 